\title{
THE USE OF INTERNATIONAL LAW IN THE DOMESTIC COURTS OF THE UNITED KINGDOM
}

\author{
Rabinder Singh $Q C$
}

The MacDermott Lecture 2005*

\section{Introduction}

While international law might traditionally have been confined to regulating relations between States, its scope today is ever expanding. One example of that expansion is the extent to which - more and more - international law is being invoked before domestic courts by individuals, corporations and nongovernmental organisations. Certainly international law remains by and large about the affairs of States, but it is also, and increasingly, aimed at nonState entities and individuals - whether because of international human rights treaties, environmental regulation, or international criminal law rules, to name but three developments since World War II.

In recent years the United Kingdom's courts have seen a number of high profile domestic cases involving international law arguments. We shall see that the courts' receptiveness to international law arguments has been mixed, and that the mixed reaction has revolved around the courts' concerns about two principal issues. The first is the question of international law's proper place in domestic law: that is, the extent to which it is correct to invoke international law in the first place. And to the extent that international law was correctly invoked in the case at hand, the second issue becomes relevant, namely, whether other considerations preclude the court from ruling on the questions that the international law arguments raise. The second issue might be described as being one of justiciability, and has tended to lead to the exercise of judicial restraint.

\section{The Proper Place of International Law in UK Domestic Law}

Beginning with the first issue - the place which international law properly occupies within the domestic legal system - we must appreciate that international law, as a law made principally by and between States, does not provide norms that can be automatically pleaded before domestic courts. There are two main sources of international law: treaty law and customary international law. Parties in national courts have first to negotiate their way around various principles before they can safely call international treaties or customary international law into service in their domestic cases. The principles are varied and complex, but certain recent cases provide useful illustrations of the most important principles and help to explain the interaction of international law and domestic law.

\footnotetext{
Given at Queen's University Belfast on 20 April 2005. I would like to thank Max du Plessis, a member of the Matrix research panel, for assistance in preparing this lecture.
} 
If we start with the classic source of international law - treaties - we see that treaties which the Executive enters into at the international level do not without more become part of our domestic law, and cannot be relied upon directly as sources of legal rights. This "dualist" position - as it is sometimes called - means that any rule or principle of international law can only have effect within the domestic legal system if it is expressly and specifically 'transformed' into municipal law by the use of an appropriate constitutional machinery, such as an Act of Parliament. ${ }^{1}$

The prerogative power of the Crown, which in the United Kingdom possesses the constitutional authority to enter into treaties, cannot be impugned by the courts. ${ }^{2}$ The position is as Lord Oliver of Aylmerton described it in J H Rayner $v$. Department of Trade and Industry:

'[A]s a matter of the constitutional law of the United Kingdom, the royal prerogative, whilst it embraces the making of treaties, does not extend to altering the law or conferring rights on individuals or depriving individuals of rights which they enjoy in domestic law without the intervention of Parliament. Treaties, as it is sometimes expressed, are not self-executing. Quite simply, a treaty is not part of English law unless and until it has been incorporated into the law by legislation'.

A knock-on effect of what Lord Oliver has described is that while the treaty or its relevant provisions might be directly transformed by a specific statute think for instance of how the rights in the European Convention on Human Rights have been 'brought home' by the Human Rights Act $1998^{4}-$ it is the specific statute to which courts will thereafter give effect. ${ }^{5}$

1 See generally Malcolm Shaw, International Law, (2003) $5^{\text {th }}$ Edition, p.129. Terminology may lead to confusion in this context: it has become commonplace for English lawyers to refer to the need for a treaty to be "incorporated" but international lawyers use the term "transformation" to contrast it with the doctrine of "incorporation", which makes rules of customary international law automatically part of the common law and does not require enactment by Parliament: see further Trendtex Trading $v$ Bank of Nigeria [1977] 1 QB 529, 554 (Lord Denning MR).

2 See Council of Civil Service Unions v Minister for the Civil Service [1985] AC 374,418 . The exercise of the prerogative power to enter into a treaty is considered beyond judicial review, so that the desirability of entering into a treaty cannot be challenged in the courts (see $R \vee$ Secretary of State for Foreign Affairs ex $p$ ReesMogg [1994] QB 552).

3 [1990] AC 418, 550. See too Halsbury's Laws of England, 'War and Armed Conflict', Vol. 49(1), $4^{\text {th }}$ Edition, para.517.

4 The text of the Convention rights are set out in Schedule 1 of the Human Rights Act 1998 and given effect largely by sections 3 and 6 .

5 See also the statement of Lord Hoffmann in $R \mathrm{v}$ Lyons and Others [2003] 1 AC 976, para.47, discussed immediately below: '[I]t is firmly established that international treaties do not form part of English law and the English courts have no jurisdiction to interpret or apply them . . . Parliament may pass a law which mirrors the terms of the treaty and in this sense incorporates the treaty into English law. But even then, the metaphor of incorporation may be misleading. It is not the treaty but the statute which forms part of English law' (para.27). See also, in the context of an appeal from the Court of Appeal of Northern Ireland, In re McKerr [2004] 1 WLR 807, para.25 (Lord Nicholls of Birkenhead); para.48 (Lord Steyn); para. 63 (Lord Hoffmann); para.74 (Lord Rodger of Earlsferry); and para. 90 (Lord 
The implications are important. Lord Hoffmann has said the following in $R$ v Lyons and Others: ${ }^{6}$

"International law does not normally take account of the internal distribution of powers within a State. It is the duty of the State to comply with international law, whatever may be the organs which have the power to do so. ... In domestic law, however, the position is different. The domestic constitution is based upon the separation of powers. In domestic law the courts are obliged to give effect to the law as enacted by Parliament. This obligation is entirely unaffected by international law."7

The facts in Lyons concerned the convictions in the Guinness trial, convictions which had depended, to a large degree, on answers that the accused had given to DTI inspectors armed with statutory powers to compel answers. In two separate judgments the European Court of Human Rights held that their right against self-incrimination under Article 6 of the Convention had been violated; their trials were thereby rendered unfair. However, those judgments did not result in the quashing of the convictions. That is a matter for national law. The applicants, understandably, sought the quashing of their convictions, arguing that the English courts were organs of the state and therefore obliged to give effect to the state's international obligations, in particular the obligation to give effect to a judgment of the European Court of Human Rights. The House of Lords disagreed. It held that the admissibility of the evidence which had been lawfully introduced against the defendants according to the domestic law at the time of their trial could not be impugned under the European Convention on Human Rights. Lord Hoffmann, while expressing admiration at the resourcefulness of counsel's argument, held that its 'foundations rest upon sand'. The statutory language governing the admission of the evidence was clear: it permitted no room for the application of international law standards.

The effect of this traditional dualist position regarding treaties is that there is very little room for the legal practitioner to draw upon the treaty in a municipal case. ${ }^{8}$ Very little room, however, does not mean no room at all. So long as a statute does not clearly trump the application of international law, there are certain situations where an unincorporated treaty may still find its use in an advocate's legal arsenal, by and large through its 'indirect' effect in domestic law. For a start, the presumption of compatibility in UK law secures a place for unincorporated treaties in the sphere of domestic law. There is a presumption that where there is an ambiguity, domestic law will be interpreted in a way which does not place the United Kingdom at odds

Brown of Eaton-under-Heywood). $C f . R(S)$ v Secretary of State for the Home Department [2004] 1 WLR 219, para.66 (Lord Rodger of Earlsferry).

6 [2003] 1 AC 976, para.47.

7 Para.40.

8 Note, however, that it has recently been suggested that the dualist approach may require "crticial re-examination" in the context of human rights treaties: In re McKerr [2004] 1 WLR 807, para.50 (Lord Steyn). 
with its international obligations. As Lord Bridge of Harwich explained in Brind: ${ }^{9}$

"[I]t is already well settled that, in construing any provision in domestic legislation which is ambiguous in the sense that it is capable of a meaning which either conforms to or conflicts with the Convention, the courts will presume that Parliament intended to legislate in conformity with the Convention, not in conflict with it."

Subsequent developments suggested that ambiguity is in fact not needed but rather that there is a presumption that Parliament does not intend by general words to infringe human rights, in the absence of express language or necessary implication to the contrary. This is sometimes called the "principle of legality': see $R$ v Secretary of State for the Home Department, ex p. Simms. ${ }^{10}$ Even now that the Human Rights Act is in force in the UK, this doctrine has a continuing role to play in relation to the numerous international human rights treaties which have been ratified but not incorporated by statute into domestic law, e.g. the 1989 UN Convention on the Rights of the Child. In the recent case of Av Secretary of State for the Home Department, in which the House of Lords held that the UK's derogation from Article 5 of the ECHR was unlawful, Lord Bingham of Cornhill referred at length to international materials which he accepted were "not legally binding on the United Kingdom"11 and yet which he found to be illuminating in answering the questions before the House. Such materials are sometimes called "soft law" and I predict that our higher courts will become increasingly receptive to their use in the future.

The presumption of compatibility may operate in various ways before the UK courts, whether to assist in clarifying the common law, ${ }^{12}$ or in the interpretation of legislation, ${ }^{13}$ or in determining the lawful remit of executive discretion. ${ }^{14}$ And, in appropriate cases, the presumption allows for an unincorporated treaty to be used as a guide to UK judges of the correct path their decisions ought to take; that is, as an influence upon judicial discretion and in shaping the common law concept of "public policy".

Kuwait Airways Corporation ${ }^{15}$ may now be regarded as the leading authority on this subject. After its invasion of Kuwait on 2 August 1990, the Iraqi regime passed resolutions proclaiming Iraqi sovereignty over Kuwait. Upon seizing Kuwait Airport, Iraqi forces removed ten commercial aircraft belonging to Kuwait Airways Corporation and flew them to Iraq. Thereafter Iraq passed resolution 369 which purported to transfer ownership of the commercial aircraft to Iraqi Airways Company. Kuwait Airways

$9 \quad R \mathrm{v}$ Secretary of State for the Home Department ex p. Brind [1991] AC 696 at 747.

10 [2000] 2 AC 115, 131 (Lord Hoffmann).

11 [2005] 2 WLR 87, para.63.

12 See $R$ v Mid Glamorgan Family Health Service ex p. Martin [1995] 1 WLR 110, $118 \mathrm{H}$, per Evans LJ.

13 See $R$ v Secretary of State for the Home Department ex p. Venables [1998] AC 407 at 499, per Lord Browne-Wilkinson.

14 See $R$ v Secretary of State for the Home Department ex p. Norney [1995] Admin LR 861 at 871, per Dyson J.

15 [2002] 2 AC 883. 
Corporation brought proceedings in England for return of the aircraft or payment of damages, and the matter came before the House of Lords. One of the defences raised by Iraqi Airways Company was that resolution 369 was to be recognised as a foreign 'act of state' - a governmental act affecting property which was recognised under Iraqi law - and which was to be respected. The manner in which Kuwait Airways Corporation responded to this defence was to rely on the UK's obligations, pursuant to an unincorporated treaty, the UN Charter and its prohibition on the use of force, and the resolutions of the Security Council condemning the invasion of Kuwait as a breach of international peace and security. Lord Steyn's description of the counter-argument by Iraqi Airways that no reliance could be placed on unincorporated treaties, was terse:

"Marching logic to its ultimate unreality, counsel for IAC submitted that the UN Charter and Security Council Resolutions are not incorporated into our law and must be disregarded." 16

Coming to the opposite conclusion, Lord Steyn held that it would be 'contrary to the international obligations of the United Kingdom were its courts to adopt an approach contrary to its obligations under the United Nations Charter and under the relevant Security Council Resolutions' and that it thus followed that 'it would be contrary to domestic public policy to give effect to Resolution 369 in any way'. ${ }^{17}$ In similar vein Lord Nicholls of Birkenhead said:

"The leading example cited in this country . . . is the 1941 decree of the National Socialist Government of Germany depriving Jewish émigrés of their German nationality and, consequentially, leading to the confiscation of their property. Surely Lord Cross of Chelsea was indubitably right when he said that a racially discriminatory and confiscatory law of this sort was so grave an infringement of human rights that the courts of this country ought to refuse to recognise it as a law at all: Oppenheimer v Cattermole [1976] AC 249, 277-278. When deciding an issue by reference to foreign law, the courts of this country must have a residual power, to be exercised exceptionally and with the greatest of circumspection, to disregard a provision in the foreign law, when to do otherwise would affront basic principles of justice and fairness ... Gross infringements of human rights are one instance ... But the principle cannot be confined to one particular category of unacceptable laws."18

The decision of the House of Lords on the "extraordinary facts"19 in Kuwait Airways suggests that in certain cases litigants may indeed rely upon an unincorporated treaty as a source of international law before a domestic UK court, and that such a source acts as a guide to the development of judicial

16 Para.114.

17 ibid.

18 At 1078-1079.

19 See the description by Janeen Carruthers and Elizabeth Crawford, "Kuwait Airways Corporation v Iraqi Airways Company", (2003) 52 ICLQ 760 at 760. 
policy. Of equal importance is the Court's stance on the question of justiciability, a vitally important topic to which I will return.

Having touched on the direct and indirect effect of treaty law in the domestic sphere, we now need to ask ourselves about that second source of international rules - customary international law. Customary international law consists of rules which are not to be found in treaties but arise from a combination of state practice and what is called opinio juris (a sense of obligation that the practice is required rather than just voluntary $)^{20}$. What is the status of customary international law before domestic courts? English courts have since the $18^{\text {th }}$ Century stated that customary international law is part of the common law. ${ }^{21}$ This doctrine proceeds from the idea that international law is part of the municipal law automatically without the need for the interposition of a constitutional ratification procedure: therefore no Act of Parliament is required to transform it into domestic law. The most famous exposition of this stance is that of Blackstone, who declared in his Commentaries that:

"[T]he law of nations, wherever any question arises which is properly the object of its jurisdiction, is here adopted in its full extent by the common law, and it is held to be a part of the law of the land." 22

Strictly speaking, this statement is too wide because, as we have seen, it is not true of treaties. But as far as customary international law is concerned, the doctrine has been applied in numerous cases in England. ${ }^{23}$ As such, the general rule ${ }^{24}$ is that customary international law is part of the common law, and this then 'provides lawyers a hook on which to hang their public international arguments'. ${ }^{25}$

20 See generally $R$ (European Roma Rights Centre) v Immigration Officer at Prague Airport [2005] 2 WLR 1, para.23 (Lord Bingham of Cornhill).

21 Triquet v Bath (1764) 3 Burr 1478.

22 "Commentaries", IV, Chapter 5, cited in Shaw, International Law, (2003), $5^{\text {th }}$ ed., p.129.

23 See Peter Malanczuk, Akehurst's Modern Introduction to International Law, $7^{\text {th }}$ Revised Edition (1997), 69. However, it is worth noting that since English courts look largely to English judgments as the main evidence of international customary law, in practice there is somewhat of a blurring between the incorporation and transformation doctrines.

24 There are a number of situations, however, which constitute exceptions to the general rule, and in which English courts cannot apply customary international law. For example, if there is a conflict between customary international law and an Act of Parliament or judicial decision, the English Act of Parliament or judicial decision prevails. However, where possible, English courts will interpret Acts of Parliament so that they do not conflict with customary international law (Malanczuk op. cit. 69). It is also accepted that English courts are probably free to depart from earlier judicial precedents laying down a rule of international law if international law has changed (see Trendtex Trading Corporation v Central Bank of Nigeria, [1977] QB 529).

25 See Sam Wordsworth, "Public International Law in the English Courts", p.1, available at <www.oxfordlawsoc.com/files/verdict/MT03/Sam\%20Wordsworth\% 20Art.doc $>$. 
It goes without saying, however, that any alleged rule of customary law must be proved to be a valid rule of international law and not merely an unsupported assertion. As Lord Macmillan put it in The Christina, ${ }^{26}$ for the courts to apply a rule of customary international law, it must have 'attained the position of general acceptance by civilised nations as a rule of international conduct, evidenced by international treaties and conventions, authoritative textbooks, practice and judicial decision' ${ }^{27}$ So, in Pinochet, the House of Lords - while denying immunity to Senator Pinochet as a former head of state - nonetheless discerned sufficient evidence of state practice and opinio juris to conclude that under customary international law a state is entitled to expect that its serving head of state will enjoy a measure of immunity from the jurisdiction of the courts of other states. ${ }^{28}$

Of course, the evolving nature of customary international law and associated difficulties of proof provide at one and the same time an opening and a risk. Lawyers are provided with an opening to be creative in making arguments involving customary international law. But in the background is the attendant risk that such creativity will not be matched by the court's conclusion on the status of the rule that has been called into service, or by the court's willingness to go where no other court might have gone before. An example of this difficulty is provided by the Abbasi case - another decision which we shall return to in our discussion of justiciability. $\mathrm{Mr}$ Abbasi, a British national who was captured by US forces in Afghanistan, was until this year detained at Guantanamo Bay in Cuba. He and other detainees had found it impossible to obtain any relief before the US courts to establish definitively their status and to challenge continued detention. The applicants sought by judicial review in England to compel the Foreign and Commonwealth Office to exercise its international law power of diplomatic protection and to make representations on Mr Abbasi's behalf to the US Government.

In respect of the diplomatic protection point, the applicants, while conceding that customary international law at the time of the hearing did not provide $\mathrm{Mr}$ Abbasi with a definitive right to diplomatic protection, argued that there was nothing preventing the Court from developing such a right within domestic law. Citing a range of sources which suggested that international law is moving towards the recognition of such a right, the applicants submitted, boldly, that 'our municipal law should lead so that international law may follow.' The Court of Appeal, however, balked at this task, and declared that '[i]t is clear that international law has not yet recognised that a State is under a duty to intervene by diplomatic or other means to protect a citizen who is

26 [1938] AC 485.

27 At 497.

${ }_{28} R v$ Bow Street Metropolitan Stipendiary Magistrate, ex p. Pinochet Ugarte (No. 3) [2000] 1 AC 147. That finding has been affirmed by the recent decision of the International Court of Justice in its Arrest Warrant decision (Democratic Republic of Congo v Belgium [2002] ICJ Rep 8. See especially para.58 where the ICJ found that it was unable to deduce under customary international law 'any form of exception to the rule according immunity from criminal jurisdiction and inviolability to incumbent [senior Government officials like Ministers of Foreign Affairs and Heads of State], where they are suspected of having committed war crimes or crimes against humanity'. 
suffering or threatened with injury in a foreign State.' As such, said Lord Phillips MR, 'it does not seem to us that [the applicant] can derive any assistance from established principles of international law'. ${ }^{29}$

\section{Justiciability}

Discussion of Abbasi brings me to the second issue confronting a lawyer in the UK when attempting to advance international law arguments before a domestic court. As I said earlier, even if international law is correctly invoked in the case at hand, other considerations may preclude the court from ruling on questions of international law. Two recent decisions - one of which is Abbasi, the other the CND case - paint the picture vividly. They reveal that the sensitive nature of foreign relations and national security weigh heavily with domestic courts when confronted with international law arguments.

In Abbasi we have seen that the applicants sought an order for diplomatic protection from the UK Government. In pressing this claim, the applicants put arguments before the Court of Appeal to show that the United States was in the process of violating their human rights and that, in the circumstances, the Foreign Secretary was under a duty under domestic public law to take positive steps to redress the position, or at least give a reasoned response to the request for assistance. One of the arguments raised by the Government was that the Court was being improperly asked to make a ruling on the legality of US conduct at Guantanamo Bay - in effect, a ruling which would find the United States to be acting in violation of international law. According to the argument for the Foreign Secretary ${ }^{30}$ this would run contrary to the classic statement of judicial restraint made by Lord Wilberforce in Buttes Gas \& Oil v Hammer. ${ }^{31}$ Lord Wilberforce there stated that there is 'a general principle that the courts will not adjudicate upon the transactions of foreign sovereign states', and deemed it 'desirable to consider this principle ... [as] one of judicial restraint or abstention' . ${ }^{32}$

The Court of Appeal in Abbasi, in a progressive jurisprudential move, rejected the Government's broad contention. It did so by relying first on the House of Lords' judgment in the Kuwait Airways case, ${ }^{33}$ which we have already encountered, and which updates the law on judicial restraint. A passage in the judgment of Lord Nicholls in Kuwait Airways identified the modern limits to the principle of judicial restraint. One of those limits, said Lord Nicholls in reference to the Iraqi invasion, is that the judiciary need not

${ }^{29} R$ (Abbasi) v Secretary of State for Foreign and Commonwealth Affairs [2003] UKHRR 76, para.69. See also, in the context of action which was said to be taken to prevent a crime against peace (namely the invasion of Iraq in March 2003), $R$ v Jones (Margaret) [2005] QB 259, where the English Court of Appeal (Criminal Division) held that there was no sufficiently settled definition of a crime of aggression under international law so as to be a "crime" in domestic law within the meaning of section 3 of the Criminal Law Act 1967. The case is due to be heard by the House of Lords in February 2006.

30 See para.32 of the judgment.

31 [1982] AC 888.

32 ibid., at 931.

33 (nos. 4 and 5) [2002] 2 AC 883, para.26. 
'shut their eyes to a breach of an established principle of international law committed by one state against another when the breach is plain'. ${ }^{34}$

The Court in Abbasi went further by drawing on immigration law. In asylum cases, where the issue is often whether the applicant for asylum has a wellfounded fear of persecution if removed to a third country, the Court pointed out that 'consideration of the claim for asylum frequently involves ruling on allegations that a foreign state is acting in breach of international law or human rights.' 35

The Court of Appeal was openly concerned about ' $\mathrm{Mr}$ Abbasi's predicament' - in particular, the undisputed fact that Mr Abbasi was (at that time $)^{36}$ being denied access to court to challenge the legality of his detention. And it allowed itself an opening to review steps taken by the UK Government to relieve this predicament on the basis that '[i]n apparent contravention of fundamental principles recognised by both [the US and the $\mathrm{UK}$ ] and by international law, Mr Abbasi is at present arbitrarily detained in a "legal black hole"., 37

Abbasi thus provides a foothold for a lawyer in the UK facing the mountain of judicial restraint. One senses the height of this mountain, however, from the eventual decision given. The Court of Appeal was sufficiently concerned about 'Mr Abbasi's predicament' to find that he had a legitimate expectation that the Government would consider making representations to the United States. But beyond this, it would not go. On the facts it found that $\mathrm{Mr}$ Abbasi's case had indeed been considered by the Foreign and Commonwealth Office, and, finding refuge on the top of the mountain, concluded as follows:

"On no view would it be appropriate to order the Secretary of State to make any specific representations to the United States, even in the face of what appears to be a clear breach of a fundamental human right, as it is obvious that this would have an impact on the conduct of foreign policy, and an impact on such policy at a particularly delicate time." 38

If there were any doubts about the continuing potency of the doctrine of judicial restraint, then the $C N D$ case $^{39}$ ought to lay them to rest. The decision, given in December 2002, relates to the controversial invasion of Iraq by US-led forces in March 2003, which was already widely anticipated; and involved an investigation by the courts of the legality of the proposed use of force by the Crown. The Campaign for Nuclear Disarmament brought an application against the Prime Minister and others, seeking a declaration on whether UN Security Council Resolution 1441 authorised states to take military action in Iraq. In the words of Simon Brown LJ:

34 Para.26, Kuwait Airways.

At para.53.

36 Now cf. Rasul v Bush 542 US - (2004).

37 Para.64.

38 Para.107(ii).

$39 R$ (Campaign for Nuclear Disarmament) v The Prime Minister of the United Kingdom and Others [2002] EWHC 2777 (Admin) (17 December 2002). 
"In short, the court is being invited to declare that the UK Government would be acting in breach of international law were it to take military action against Iraq without a further Resolution. It is, to say the least, a novel and ambitious claim." 40

The international law that the applicant invoked before the Court was limited to customary international law, more specifically, the breach of the ius cogens norm outlawing the use of force in international relations. The term ius cogens refers to peremptory norms of international law which are so fundamental that they permit of no derogation by any state. Following from our earlier discussion about the proper place of international law within UK domestic law, this is significant. CND, anticipating that the Government would maintain that any use of force was authorised on the Government's understanding of existing unincorporated Security Council resolutions, placed its reliance on customary international law. In this way CND was able to argue that its claim was based on a breach of law over which the Court had jurisdiction, since, as we have seen, customary international law is part of domestic law.

The Divisional Court rejected the application, and did so on two principal bases which appear to be interrelated. The first problem, said the Court, is that the applicants' reliance on customary international law did not avoid the real problem at hand, namely, the proper interpretation of Resolution 1441 an unincorporated international instrument. The Court concluded that the applicants sought 'a ruling on the interpretation of an [unincorporated] international instrument, no more and no less', and could not therefore 'escape the rule which Lyons exemplifies by seeking to invoke the principle of customary international law.' ${ }^{\prime 1}$

The second problem, in the Court's eyes, was that the issues raised in the case were not justiciable. With the question: '[h]ow could our assumption of jurisdiction here [to interpret unincorporated Resolution 1441] be regarded around the world as anything other than an exorbitant arrogation of adjudicative power?'42 Simon Brown LJ disclosed what the Court saw as the real obstacle confronting the applicants. That obstacle was the 'general rule' that, 'in the interests of comity, domestic courts do not rule on questions of international law which affect foreign states'. ${ }^{43}$ The rule of noninterpretation of unincorporated international legal standards appears to look like more than a principle of judicial restraint and to be a rule of jurisdiction - at least in the sense that the court regards itself as having none. ${ }^{44}$ And certainly this appears to be the case in the CND decision. The Court found itself declining to embark upon the determination of the issue because to do so 'would be damaging to the public interest in the field of international relations, national security or defence'. ${ }^{45}$

40 Para.2.

41 Para.37.

42 Para.37.

43 Para.38.

44 Colin Warbrick, 'International Law in English Courts - Recent Cases', (2003) 52 ICLQ 815, 823 .

45 Para.47(ii). 
The applicants had submitted that 'the only proper course for government to take is to conduct its international relations openly in accordance with whatever advice it has received', a view that Simon Brown LJ took to 'represent a singularly utopian view of international affairs'. ${ }^{46}$ Perhaps, as the world order is in danger of rupture following the deeply controversial Iraqi conflict, one of the goals will be to ensure that international relations are conducted more openly, and the pressure on governments, including our own, is mounting. Sir Franklin Berman, a former chief legal adviser to the FCO, is reported to have said the following in the context of the government's refusal to disclose its full reasons for going to war:

"For a decision to go to war, especially when the government claims to be acting on behalf of the international community, they ought to explain in the necessary detail the basis on which they were acting." 47

As is well-known, the debate about disclosure of the advice given by the Attorney General as to the legality of the attack on Iraq in 2003 continues unabated. Professor Philippe Sands has recently published a book, Lawlesss World, in which he discusses the question at length and concludes that: "I suspect that the cloud will continue to hang over those most closely associated with the advice until it is published in full." 48

The decisions in Abbasi and CND reveal that, where there is evident tension between reliance on international law and the policy considerations relied upon by the Executive, domestic courts will not allow the international law arguments to resonate too loudly.

What are we to make of this self-imposed judicial caution? If one thinks back to our discussion of Kuwait Airways, and Lord Steyn's willingness to have recourse to the unincorporated UN Charter's prohibition on the use of force and the relevant Security Council resolutions in that case, it might be questioned why, for example, the Court in $C N D$ was so reluctant to do the same. Certainly the UN Charter's prohibition on the use of force relied on by Lord Steyn reflects the same principle of customary international law that the court was asked to have regard to in the $C N D$ case.

One difference, it would seem, is that the House of Lords had not been asked to interpret the real meaning of the unincorporated instruments, while the judges in $C N D$ felt that that is precisely what was required of them in relation to Resolution 1441. What appears to have been crucial is the fact that in $C N D$ the application of international law prohibiting the use of force did not dovetail with the Executive's policy considerations. In this light the House of Lords' judgment in Kuwait Airways can also be more readily understood. The House of Lords knew that its decision would accord with the policy considerations of the Executive. One of those considerations, as

46 Para.45, CND case.

47 The Guardian, 'War QC sticks to his guns', Monday, March 1, 2004, available at <http://www.guardian.co.uk/guardianpolitics/story/0,3605,1159222,00.html>.

48 Philippe Sands, Lawless World: America and the Making and Breaking of Global Rules (2005), p.201. After this lecture was delivered, the text of the Attorney General's advice of 7 March 2003 was released by the Government after extracts from it had been leaked and were published in the media. 
expressed by Sir Franklin Berman (then FCO Legal Adviser) in a letter before the Court, was that the UK considered itself bound by the Security Council resolutions which condemned the invasion of Kuwait as a breach of international peace and security ${ }^{49}$ - the Executive's policy considerations were a mirror of the international law arguments pleaded before the House.

What is not clear then is whether lawyers in cases to come will achieve success with facts any less "extraordinary" than those in Kuwait Airways and involving international law arguments which chime any less with the Executive's policy considerations. The best that might be hoped for is an ability to scale the mountain of judicial restraint in the appropriate circumstances. Abbasi as we have seen provides something of a foothold. A domestic court is free to express a view in relation to what it conceives to be a clear breach of international law, particularly in the context of human rights. ${ }^{50}$ But even in Abbasi the lawyers failed to scale the mountain face in respect of their request. More disconcertingly, the $C N D$ decision suggests that climbing might not even be worth the effort.

In the national context, courts readily accept that they are the guardians of the domestic law and the constraints it places on government action, even in the face of national security considerations the Executive might advance. As Colin Warbrick has recently pointed out: 'however difficult an adverse judgment might be for the execution of the government's chosen policy, the court will not decline to give its judgment and will expect it to be followed.' Lord Steyn has had recent occasion to highlight this role for the courts in the context of the detention of prisoners at Guantanamo Bay. ${ }^{51}$ Speaking extrajudicially about the terrible injustices in modern times that national governments have 'perpetrated in the name of security on thousands who had no effective recourse to law', ${ }^{52}$ Lord Steyn stressed that 'instinctive trust in public servants, executive or judicial, has been replaced by a culture requiring in principle openness and accountability from all entrusted with public power'. 53

But in the realm of international law and foreign policy, things appear so far to be different. And where international law and government's foreign policy do not openly mirror each other, the mountain of judicial restraint takes shape. The effect of this edifice, it appears to me, is that the constraints of international law stand the risk of being sacrificed on the altar of government's chosen policy, no matter how bad, ill-conceived, or partisan that policy might be. In Professor Warbrick's words:

"[I]t appears that the judges in $C N D$ took the position that international law is a part of the process of international relations, not a fetter upon it. While the judgment does not go quite so far as to say that the government needs the freedom to

49 See para.114, Kuwait Airways.

50 Para.57, Abbasi.

51 See Johan Steyn, "Guantanamo Bay: The Legal Black Hole" (2004) 53 ICLQ 1.

52 At p.2.

53 At p.5. 
act contrary to international law, it does take a robust view of how international law works in the service of policy." 54

Professor Warbrick's words allow me an opening to express some of my own opinions surrounding this question. I believe that we should be wary of allowing international law to be subservient to the demands of national security or the conduct of foreign affairs. The demands of international law should ordinarily come before the demands of comity, which may otherwise be a cloak for realpolitik; and international law should provide the framework of rules within which international relations are conducted. While other countries might allow or believe otherwise, international law ought to be a fetter on the way the UK conducts its foreign affairs. To believe otherwise is to place the type of 'instinctive trust' in public servants, executive or judicial, that Lord Steyn was talking about in the context of domestic policy. I think the time may have arrived for us to strive also for a culture of openness and accountability in the international context, and to use the courts to interrogate whatever instinctive trust may remain in those entrusted with public power in the field of foreign policy and international relations.

\section{The Future}

Let me look towards the future. The Iraq war and the subsequent occupation of Iraq remain the most high profile sources of litigation that domestic courts have to confront. Two examples may suffice.

The first relates to the very issue that was at the core of the CND decisionthe legality of the war. In cases involving protestors in Southampton Magistrates' Court and Bristol Crown Court rulings have been made applying the $C N D$ decision even to criminal charges brought against individuals who wished to argue that they acted as they did to prevent an illegal war. In the judgment of Grigson J, given at Bristol Crown Court in the case of $R v$ Pritchard and others (12 May 2004), it was held that the principle of non-justiciability in $C N D$ applies even where a domestic court has to decide whether or not a defendant has a defence available to a criminal charge. The Court of Appeal (Criminal Division) dismissed an appeal in July 2004. ${ }^{55}$ However, it did say:

"There is, it seems to us, considerable force in the argument that the $C N D$ case does not, in itself, provide the answer to justiciability in the present case ..." 56

The second type of case to come before the courts has been brought by the families of Iraqi civilians killed by British soldiers. ${ }^{57}$ The Divisional Court

54 Colin Warbrick, 'International Law in English Courts - Recent Cases', (2003) 52 ICLQ 815, 824.

$55 R \mathrm{v}$ Jones (Margaret) [2005] QB 259. The case is due to be heard by the House of Lords in February 2006.

56 Para.14 (Latham LJ, giving the judgment of the Court). Another case, decided by the Divisional Court after this lecture was delivered, also considered similar legal issues: Ayliffe v DPP [2005] EWHC 684 (Admin) (21 April 2005).

57 See The Independent, 'Britain on trial for Iraqis killed by its troops', $1^{\text {st }}$ March 2004, available at <http://news.independent.co.uk/low_res/story.jsp? story $=496536 \&$ host $=3 \& \operatorname{dir}=60>$. 
heard six test cases last year in which three preliminary issues arose: (1) whether the ECHR applied to British forces in Iraq in the circumstances of those cases; (2), whether the HRA applied; and (3) if so, whether the procedural obligation under Articles 2 and 3 of the ECHR to conduct an investigation into deaths and alleged torture which may have been caused by state agents was breached in those cases. Judgment was given on 14 December 2004. ${ }^{58}$

The Divisional Court held, first, that only one of the cases before it fell within the jurisdiction of the UK, the case of Mr Mousa, on the ground that he was detained by British forces in a prison and so there was sufficient control over him to bring him within their jurisdiction. The Court held, secondly, that Mr Mousa's case also fell within the scope of the Human Rights Act, which to that extent does have some extra-territorial effect. Thirdly, the Court held that there had been a breach of the procedural obligation in Articles 2 and 3 in that there had not been an adequate and timely investigation of his alleged torture and killing by British soldiers. I hope I summarise the decision fairly if briefly but I will not comment on it in detail because the case is going to the Court of Appeal. For present purposes, what is of interest is that the Court was inevitably required to adjudicate on intricate questions of international law relating to the concept of a state's "jurisdiction" because that is the concept used in Article 1 of the ECHR. ${ }^{59}$

These examples illustrate the contemporary relevance of international law issues in UK courts. They also illustrate, as do the other cases I have spoken about, the importance of the issues at stake. Democracies face threats to national security, and controversial decisions about foreign policy are taken all the time. In the climate of our extraordinary times, however, it is not only our security and questions of foreign policy that are at issue. At issue also is the very nature of our democracy and its response to acts of war and international terrorism. Speaking of the outrage against international and human rights law that Guantanamo Bay represents, Lord Steyn asked whether our government ought to make plain publicly and unambiguously the utter lawlessness at Guantanamo Bay. To Lord Steyn the answer might be found in John Donne's famous vision of no man being an island unto itself - where 'any man's death diminishes me, because I am involved in Mankind'. 60

Certainly, for effect to be given to this vision then comity and the precarious nature of international relations must in principle remain subservient to the demands of justice and the standards set by the world's law. And while Lord Steyn's challenge is limited to the UK government and its politicians, the difficulty remains for lawyers, once they have correctly invoked applicable international law in UK courts, to convince judges that the challenge is one that applies also to the judiciary.

${ }^{58} R$ (Al Skeini) v Secretary of State for Defence [2005] HRLR 3.

59 Note that, although Article 1 itself is not included in Sch.1 to the Human Rights Act 1998, the Divisional Court considered that it was relevant to the scope of the Act

60 Johan Steyn, “Guantanamo Bay: The Legal Black Hole”, (2004) 53 ICLQ 1, 15. 
As Lord Hoffmann said in Rehman, "it is important neither to blur nor to exaggerate the area of responsibility of the executive" and the courts may have to decide "issues which at no point lie within the exclusive province of the executive." 61 I would suggest that questions of pure law, as opposed to the merits of a policy, are for the courts and certainly not within the exclusive province of the executive.

\section{Why does international law matter in the present context?}

I would like to try to answer the question as follows:

(a) It matters to governments, which say that they wish to comply with international law and that they are doing so - that has certainly been the position of the British Government in relation to the Iraq war of 2003. In a democracy they should be accountable for that view.

(b) It matters to our armed forces - who are well-disciplined and trained to comply with the law, including international law. It has emerged that in the week leading up to the invasion of Iraq in March 2003 Lord Boyce (then Chief of the Defence Staff) required firm reassurance from the Attorney General that the invasion would be lawful. As Professor Sands puts it in his recent book, Lord Boyce "wanted to be sure that military chiefs and their soldiers would not be 'put through the mill' at the International Criminal Court." 62

(c) It matters to the public - for example, opinion polls suggested that many people wished to see a UN resolution clearly authorizing the use of force on Iraq (the so-called "second resolution") before the UK took part in any invasion. That may not be enough for some people, who would still have doubted the morality or political wisdom of attacking Iraq, but at least it would have been a good start.

(d) It matters because we should live up to our own standards. If we do not, we simply give sustenance to those who believe that the rule of law is a sham which is used by Western powers to cloak the naked use of power. Defiance of the law encourages others around the world to use violence too. This is dangerous in an increasingly dangerous world.

I can do no better than to end with a quotation from an American judge, Justice Brennan, who was a judge for many years on the US Supreme Court and said:

"Mutuality ... . serves to inculcate the values of law and order. By respecting the rights of foreign nationals, we encourage other nations to respect the rights of our citizens. Moreover, as our Nation becomes increasingly concerned about the domestic effects of international crime, we cannot forget that the behavior of our law enforcement agents abroad sends a powerful message about the rule of law to individuals everywhere. As Justice Brandeis warned in Olmstead v United States 277 US 438 (1928):

61 Secretary of State for the Home Department v Rehman [2003] 1 AC 153, para.54.

62 Philippe Sands, op. cit., p.197. 
134 Northern Ireland Legal Quarterly [Vol. 56, No. 2]

'If the Government becomes a lawbreaker, it breeds contempt for law; it invites every man to become a law unto himself; it invites anarchy. ... .' Id., at 485 (dissenting opinion)

... If we seek respect for law and order, we must observe these principles ourselves. Lawlessness breeds lawlessness." ${ }^{63}$

63 Verdugo-Urquidez 494 US 259 (1990) at 285. 